\title{
Faktor-Faktor yang Mempengaruhi Adopsi Petani dalam Penerapan Sistem Tanam Jajar Legowo di Desa Sukosari Kecamatan Kasembon Kabupaten Malang Provinsi Jawa Timur
}

\section{Factors Affecting Farmer Adoption in the Implementation of Jajar Legowo Planting System in Sukosari Village, Kasembon Sub-District, District of Malang, East Java}

\author{
Abdul Farid ${ }^{1}$, Ugik Romadi ${ }^{1}$, Djoko Witono ${ }^{2}$ \\ ${ }^{1}$ Sekolah Tinggi Penyuluhan Pertanian Malang \\ ${ }^{2}$ Balai Besar Pelatihan Pertanian Ketindan
}

\begin{abstract}
This study aims to determine factors that influence of jajar legowo planting system adoption by farmer. This study was conducted in Kasembon Sub-distict from March to May 2017. Survey with closed questionnaire method with Likert scale measurement was used on 80 respondents. Data was presented in tabulation form, and the influence of internal and external factors of farmers on the opportunity of jajar legowo system adoption was analyzed by multiple linear regression test. The results showed that the farmers attitude has a positive tendency $72.5 \%$ on the opportunity of jajar legowo planting system adoption based on the principle of jajar legowo planting system. Internal factors such as age and profitability variable of farmers showed a positive influence on the opportunity of jajar legowo system adoption, while the external factor such as price variable have a negative effect. Other variables such as education, experience, land, extension intensity, extension materials, extension methods and extension media have no effect on the opportunity of jajar legowo planting system adoption.
\end{abstract}

Keywords : Adoption, Farmer, Planting System, Jajar Legowo

\begin{abstract}
Abstrak
Penelitian ini bertujuan mengetahui faktor-faktor yang mempengaruhi adopsi petani dalam penerapan sistem tanam jajar legowo. Penelitian dilakukan di Kecamatan Kasembon pada bulan Maret sampai dengan Mei 2017. Metode yang digunakan dalam penelitian ini adalah survei dengan kuesioner tertutup dengan alat pengukuran skala Likert pada 80 responden. Data disajikan dalam bentuk tabulasi, dan pengaruh faktor internal dan eksternal petani terhadap peluang adopsi sistem tanam jajar legowo dianalisis dengan uji regresi linier berganda. Hasil penelitian menunjukkan sikap petani memiliki kecenderungan positif sebanyak 72,5\% terhadap peluang adopsi sistem tanam jajar legowo berdasarkan prinsip sistem tanam jajar legowo. Faktor internal petani menunjukkan pengaruh positif terhadap peluang adopsi sistem tanam jajar legowo adalah variabel umur dan profitabilitas, sedangkan faktor eksternal petani berpengaruh negatif adalah variabel harga. Variabel-variabel lainnya yaitu pendidikan, pengalaman, lahan, intensitas penyuluhan, materi penyuluhan, metode penyuluhan dan media penyuluhan tidak berpengaruh terhadap peluang adopsi sistem tanam jajar legowo.
\end{abstract}

Kata kunci : Adopsi, Petani, Sistem Tanam, Jajar Legowo

\section{Pendahuluan}

Pangan merupakan kebutuhan dasar utama bagi manusia yang harus dipenuhi setiap saat sehingga komoditas tanaman pangan utamanya padi merupakan suatu komoditas yang sangat penting dan strategis. Ketersediaan pangan merupakan aspek penting dalam mewujudkan ketahanan pangan karena penyediaan pangan diperlukan untuk memenuhi kebutuhan dan konsumsi pangan bagi masyarakat, rumah tangga, dan perseorangan secara berkelanjutan (Renstra Kementan 2015-2019).

Dalam rangka peningkatan produksi padi nasional, Balai Penelitian dan Pengembangan Pertanian (Balitbangtan) pada tahun 2008 telah menghasilkan Pengelolaan Tanaman Terpadu (PTT) padi sawah. Inovasi ini kemudian diadopsi dan dikembangkan oleh Direktorat Jenderal Tanaman Pangan dan diimplementasikan dalam bentuk Sekolah Lapang PTT (SL-PTT) karena salah satu komponennya adalah sistem tanam jajar legowo yang dapat meningkatkan produktivitas tanaman sebagai akibat dari meningkatnya jumlah populasi tanaman.

Berdasarkan data BPS tahun 2016, Kecamatan Kasembon dengan luas wilayah $55,67 \mathrm{Km}^{2}$ atau sekitar 1,87 persen dari luas Kabupaten Malang, terdiri dari enam desa dengan topografi sebagian besar berupa perbukitan. Terdapat empat desa berada di lereng dan dua desa berupa dataran. Desa Sukosari mempunyai topografi relatif datar dibandingkan desa lainnya.

\footnotetext{
${ }^{1}$ Korespondensi penulis

E-mail: ugik_yas@yahoo.com
} 
Dengan total lahan seluas 406,4 ha yang terdiri dari lahan sawah seluas 231 ha $(56,8 \%)$, pemukinan dan pekarangan seluas $84,7(38,2 \%)$ dan tegalan 20,2 (5\%), komoditas padi menjadi komoditas utama dalam usaha tani di Desa Sukosari yang memiliki produksi padi per musim tanam rata-rata mencapai 1.617 ton per hektar dengan rata-rata produktivitas 7 ton per hektar.

\section{Berdasarkan Programa Penyuluhan} Kecamatan Kasembon tahun 2017, Unit Pelaksana Teknis Badan Penyuluhan (UPT-BP) Kecamatan Kasembon setidaknya berusaha mempertahankan tingkat produktivitas atau bahkan dapat meningkatkan produktivitas sejalan dengan tantangan maraknya alih fungsi lahan pertanian. Upaya yang dilakukan UPT-BP Kecamatan Kasembon salah satunya adalah dengan diseminasi inovasi sistem tanam jajar legowo yang merupakan salah satu komponen teknologi PTT padi.

Diseminasi inovasi sistem tanam jajar legowo pada prinsipnya bertujuan merubah perilaku petani (pengetahuan, sikap dan keterampilan). Perubahan perilaku petani diharapkan dapat meningkatkan produktivitas, sehingga berdampak pada peningkatan kesejahteraan hidup petani itu sendiri. Hal ini sesuai dengan yang diamanatkan dalam Undang-Undang SistemPenyuluhanPertanian, Perikanan danKehutanan (SP3K) Pasal 1 Point 1 yaitu rangkaian pengembangan kemampuan, pengetahuan, keterampilan, serta sikap pelaku utama dan pelaku usaha melalui penyuluhan.

Kegiatan penyuluhan tentang sistem tanam jajar legowo di Desa Sukosari sudah sering dilakukan baik melalui SL-PTT maupun pendekatan sistem kerja "Latihan dan Kunjungan". Kegiatan tersebut bertujuan merubah perilaku petani agar mau dan mapu menerapkan sistem tanam jajar legowo dalam usahatani padi. Namun pada kondisi riil di lapangan, petani belum banyak yang menerapkannya.

Penelitian ini bertujuan untuk mengetahui faktor internal maupun eksternal yang mempengaruhi adopsi petani dalam penerapan sistem tanam jajar legowo

\section{Metode Penelitian}

Lokasi kegiatan penelitian dilakukan di Kecamatan Kasembon Kabupaten Malang pada bulan Maret sampai dengan Mei 2017. Populasi yang akan dijadikan obyek penelitian adalah petani padi sawah di Desa Sukosari Kecamatan Kasembon yang tegabung dalam Gabungan Kelompoktani Sukosari Membangun. Jumlah populasi sebanyak 382 orang anggota yang telah mendapatkan diseminasi sistem tanam jajar legowo.

Jumlah sampel ditentukan secara random sampling dengan perhitungan slovin yang menggunakan tingkat ketidakakurasian sebesar $10 \%$ sehingga menghasilkan jumlah responden sebanyak 79,25 dan dibulatkan menjadi 80 orang responden. Selanjutnya dari 80 sampel responden dilanjutkan perhitungan dengan teknik proporsional random sampling agar masing-masing kelompok tani sebagai anggota Gapoktan terwakili secara proposional sesuai jumlah anggota masing-masing kelompoktani yaitu Kelompoktani Amongtani $1=19$ responden, Amongtani $2=20$ responden, Amongtani $3=11$ responden, Amongtani $4=17$ responden dan Amongtani $5=13$ responden.

Pengumpulan data primer yang digunakan adalah metode survei melalui pengisian kuesioner tertutup dengan alat pengukuran menggunakan metode skala Likert. Teknik pengumpulan data primer melalui beberapa cara yaitu didapatkan pada saat kegiatan pertemuan kelompok ataupun menggunakan metode kunjungan dari rumah ke rumah (anjangsana). Pengumpulan data sekunder dilakukan dengan cara penelusuran data dari pihak-pihak yang berkompeten dengan program-program pemberdayaan petani seperti Penyuluh Pertanian Lapangan maupun Mantri Tani serta dokumen-dokumen yang berkaitan dengan pertanian di kantor atau instansi terkait serta penelusuran lewat internet untuk kepustakaan.

Untuk menaksir fungsi regresi populasi berdasarkan fungsi regresi sampel maka digunakan metode Kuadrat Terkecil Biasa atau Ordinary Least Square (OLS). Faktor yang diduga berpengaruh terhadap peluang petani untuk mengadopsi sistem tanam jajar legowo pada usahatani padi adalah umur (X.1), pendidikan (X.2), pengalaman (X.3), profitabilitas (X.4), lahan (X.5), harga (X.6), intensitas penyuluhan (X.7), materi penyuluhan (X.8), metode penyuluhan (X.9) dan media penyuluhan (X.10).

Ketepatan model regresi linier berganda hasil analisis diukur dengan nilai koefisien determinasi $\left(\mathrm{R}^{2}\right)$. Nilai koefisien determinasi merupakan gambaran dari proporsi keragaman (varian) total variabel tidak bebas (Y) yang dapat dijelaskan oleh variabel-variabel bebas $\left(\mathrm{X}_{\mathrm{i}}\right)$ secara bersama-sama dan menunjukkan besarnya sumbangan variabel bebas $\left(\mathrm{X}_{\mathrm{i}}\right)$ terhadap variabel tidak bebas (Y).

Pengujian hipotesis gabungan/simultan dilakukan untuk mengetahui berpengaruh nyata atau tidak nyata secara serentak seluruh variabel independen terhadap variabel dependen (Gujarati 2006). 
Hipotesis dalam penelitian ini adalah adanya pengaruh dari fakto-faktor internal maupun eksternal petani terhadap peluang adopsi petani dalam penerapan sistem tanam jajar legowo

\section{Hasil dan Pembahasan}

Desa Sukosari merupakan salah satu dari 6 desa di wilayah Kecamatan Kasembon yang terletak pada koordinat 7,4636 Lintang Selatan dan 112,1822 Bujur Timur dengan luas wilayah $\pm 4,29 \mathrm{Km}^{2}$. Secara administratif Desa Sukosari memiliki 5 Dusun (16 RW dan 34 RT).

Secara umum Desa Sukosari mempunyai topografi relatif datar dengan derajad kemiringan 8-15 derajad dengan bulan basah 6-7 bulan dan bulan kering 5-6 bulan dalam satu tahun dengan suhu udara antara 20-30 ${ }^{\circ}$. Jenis tanah di Desa Sukosari merupakan jenis tanah Entisol dan Litosol sehingga sangat cocok untuk lahan persawahan dengan $\mathrm{pH}$ tanah 5,0-6,5. Berdasarkan karakteristik lahan dan iklim maka keadaan lahan pertanian di Desa Sukosari terbagi menjadi lahan sawah dan tegalan.

Berdasarkan data dari Mantri Tani Kecamatan Kasembon, jumlah luasan lahan sawah yang sudah menerapkan sistem tanam jajar legowo masih sangat rendah yaitu kurang lebih hanya seluas 20,0 Ha $(8,66 \%)$. Gambaran kependudukan Desa Sukosari berdasarkan BPS Kabupaten Malang tahun 2017, penduduk Desa Sukosari berjumlah 6.028 jiwa dengan rincian pria sebanyak 3.093 jiwa dan wanita sebanyak 2.935 jiwa dengan rata-rata anggota keluarga sebanyak 3 orang.

Mayoritas penduduk mempunyai mata pencaharian sebagai petani dikarenakan kondisi lahan yang sangat memungkinkan untuk usaha dibidang pertanian. Usaha tani padi sawah di Desa sukosari menjadi usaha tani utama dimana hingga sampai dengan saat ini Desa Sukosari menjadi lumbung padi untuk Kecamatan Kasembon. Disamping mengusahakan padi, petani juga mengusahakan tanaman lain yaitu palawija hal ini terlihat dari pola tanam yang dilakukan yaitu "Padi - Padi - Palawija".

Kelembagaan petani di Desa Sukosari terdapat satu Gabungan Kelompoktani, 5 Kelompoktani dan 1 Kelompok Wanita Tani (KWT). Masing-masing Kelompoktani di Desa Sukosari mewakili tiap Dusun sehingga dalam satu Dusun hanya ada satu Kelompoktani.

Umurpetani berkaitan dengan pengalaman dan kematangan petani dalam melaksanakan usahataninya.
Secara umum, umur petani akan mempengaruhi kemampuan fisik dan respon terhadap hal-hal baru dalam menjalankan usahataninya. Umur petani responden Desa Sukosari berdasarkan usia produktif menurut Badan Pusat setatistik yaitu didominasi oleh responden yang berumur 15-64 tahun yaitu sebanyak 72 orang $(90 \%)$. Umur petani responden lainnya adalah di atas 64 tahun yaitu sebanyak 8 orang $(10 \%)$ sehingga dapat dikatakan bahwa umur petani responden yang dominan merupakan golongan usia produktif.

Tingkat pendidikan petani responden Desa Sukosari didominasi dengan pendidikan SD sejumlah 49 orang (61\%), sedangkan petani responden yang berpendidikan di atas SD hanya berjumlah 31 orang (39\%). Dengan tingkat pendidikan yang mayoritas SD proses penyerapan ilmu tentang teknologi sistem tanam jajar legowo masih memungkinkan untuk dilakukan walaupun membutuhkan waktu yang tidak singkat dan perlu ketekunan serta kesabaran.

Pengalaman berusahatani didominasi petani responden yang memiliki pengalaman berusahatani lebih dari 10 tahun yaitu sebanyak 71 petani (89\%). Kondisi tersebut merupakan suatu hal yang wajar karena jika kita kaitkan dengan umur petani dimana petani responden dengan umur 40 tahun ke atas mencapai 68 orang $(85 \%)$.

Distribusi luas lahan petani responden, sebagian besar mempunyai lahan yang sempit yaitu 42 orang $(52,5 \%)$ dibawah $0,51 \mathrm{Ha}$. Hal itu terjadi karena lahan yang diusahakan merupakan warisan orangtua yang telah terbagi dengan saudaranya sebelumnya. Dari lahan yang sempit sampai dengan lahan yang agak luas, biasanya petani tidak hanya mengandalkan hasil usaha tani padi saja namun ada usaha lainnya dalam rangka mencukupi kebutuhan hidupnya.

Pada penelitian ini, hasil uji t menunjukkan faktor yang berpengaruh adalah variabel umur, profitabilitas dan harga.

\section{Faktor Umur}

Faktor umur berpengaruh signifikan positif didasarkan pada keadaan karakteristik petani di Desa Sukosari yang didominasi petani kategori usia produktif yaitu umur 15-64 tahun (BPS, 2016). Faktor umur petani berpengaruh didasarkan pada kenyataan bahwa semakin tambah usia seseorang (petani) maka diikuti dengan meningkatnya kebutuhan hidup keluarga petani tersebut sehingga mau tidak mau akan selalu menginginkan peningkatan pendapatan keluarganya sehingga orientasi untuk mendapatkan 
keuntungan dalam setiap usahataninya menjadi faktor utama yang selalu dipertimbangkan. Kebutuhan untuk mendapatkan profit dalam usahatani akan memotivasi seseorang untuk membuka diri terhadap inovasi yang berpeluang dapat meningkatkan pendapatan dalam hal ini keuntungan usahatani padi tersebut. Hal tersebut sesuai dengan kajian yang dilakukan oleh Mulijanti dan Sinaga (2014) dengan judul kajian Efektivitas Pendampingan Teknologi Tanam Jajar Legowo terhadap Perubahan Sikap dan Pengetahuan Petani di Kabupaten Sumedang Jawa Barat yang menyatakan bahwa terkait dengan adanya inovasi cara tanam legowo maka umur produktif (15-64 tahun) akan lebih mudah dan cepat menerima inovasi sedangkan seseorang pada umur non produktif akan cenderung sulit menerima inovasi.

\section{Faktor Profitabilitas}

Profitabilitas pada penelitian ini adalah nilai keuntungan relatif yang menjadi motif petani dalam berusaha tani padi sawah. Faktor ini merupakan faktor yang paling berpengaruh dalam penelitian dengan nilai koefisien positif mencapai 5,074. Hal tersebut sangat beralasan karena sebagian besar penduduk Desa Sukosari berprofesi sebagai petani yang mengusahakan lahannya untuk berusahatani padi sawah. Sebagai petani yang melakukan usahatani padi sawah sebagai pekerjaan utama maka petani akan mengupayakan dengan segala cara agar usahatani padinya menghasilkan keuntungan yang tinggi. Hal ini sesuai dengan penelitian dari Ningtyas (2016) yang berjudul Tingkat Adopsi Sistem Tanam Jajar Legowo 2:1 Di Kelompok Tani Mina Sri Jaya Desa Sepanjang Kecamatan Glenmore Kabupaten Banyuwangi Jawa Timur yang menyatakan bahwa keuntungan menjadi motivasi petani untuk menerapkan sistem tanam jajar legowo 2:1.

\section{Faktor Harga}

Faktor harga pada penelitian ini berpengaruh signifikan negatif. Faktor harga ini berkaitan dengan kebiasaan dan kepraktisan operasional petani dalam menjamin kepastian terjualnya hasil panen utamanya gabah yang berpengaruh pada keuntungan relatif yang harus dicapai oleh petani. Petani pada umumnya cenderung menjual hasil panennya kepada pengepul (tengkulak) dibandingkan jika harus dijual ke Bulog yang menjadi anjuran pemerintah melalui petugas lapangan dalam rangka Program Upaya Khusus
Peningkatan Produksi Beras Nasional. Penjualan hasil panen kepada Perum Bulog dianggap sulit oleh petani karena banyak persyaratan yang harus dipenuhi. Di sisi lain, dengan bergantungnya petani terhadap serapan gabah oleh pengepul maka posisi tawar petani menjadi kurang diuntungkan karena tinggi rendahnya harga gabah petani ditentukan oleh pengepul. Hal tersebut diperburuk dengan pengaruh faktor musim dimana harga jual GKP biasanya akan terpuruk pada saat musim hujan ataupun saat panen raya.

Berdasarkan keadaan tersebut maka pada umumnya dengan naiknya hasil panen petani padi mengakibatkan turunnya harga gabah petani yang mengakibatkan menurunya tingkat keuntungan petani. Hal ini sesuai dengan hasil analisis harga gabah tahun 2015 oleh Badan Pengawas Perdagangan Berjangka Komoditi Kementerian Perdagangan yang menyatakan bahwa memasuki musim panen, dibeberapa wilayah di Indonesia harga Gabah mulai mengalami penurunan. Agar keuntungan panen yang diperoleh tidak semakin menurun dengan terus merosotnya harga gabah memasuki panen raya, maka banyak petani menjual hasil panen dengan sistem tebas. Ditambahkan juga oleh Damanik (2012) dalam penelitiannya yang berjudul Analisis Faktor-Faktor yang mempengaruhi Harga Jual Gabah Petani di Serdang Bedagai yang menyatakan bahwa faktor-faktor teknis yang mempengaruhi harga jual gabah petani yaitu upah tenaga kerja dan biaya bibit serta faktor non teknis yaitu kondisi cuaca, agen (pengepul) dan waktu panen.

Faktor yang tidak berpengaruh meliputi faktor internal dan ekternal. Faktor internal yang tidak berpengaruh adalah variabel pendidikan, pengalaman dan lahan. Sedangkan faktor ekternal tidak berpengaruh yaitu variabel intensitas penyuluhan, materi penyuluhan, metode penyuluhan dan media penyuluhan.

\section{Faktor Internal}

Faktor pendidikan tidak berpengaruh berkaitan dengan kondisi tingkat pendidikan petani di Desa Sukosari yang didominasi oleh petani yang hanya menamatkan pendidikan formal setaraf Sekolah Dasar. Seseorang dengan pendidikan tinggi pada umumnya orang tersebut akan semakin luas pengetahuannya. Menurut Notoatmodjo (2003), pengetahuan seseorang terhadap objek mempunyai intensitas atau tingkat yang berbeda-beda. Disamping itu tidak signifikannya pendidikan terhadap tingkat penerapan teknologi sistem tanam padi jajar legowo menunjukan bahwa 
pendidikan tidak mempengaruhi tingkat penerapan karena apapun tingkat pendidikan petani, baik yang tingkat pendidikannya rendah maupun yang tingkat pendidikannya tinggi di Desa Sukosari mempunyai kesempatan yang sama dalam menerapkan teknologi jajar legowo.

Faktor pengalaman dalam penelitian ini didasarkan pada pengalaman petani dalam berusaha tani padi sawah secara konvensional berdasarkan kebiasaan turun temurun. Faktor pengalaman yang tidak siginifikan terhadap adopsi sistem tanam jajar legowo juga berkaitan dengan aspek pengetahuan petani dalam memahami sistem tanam jajar legowo dimana pengetahuan petani mengenai sistem tanam jajar legowo hanya sebatas perbedaan jarak tanam sedangkan faktor lain seperti alasan penerapan jajar legowo 2:1 ataupun $4: 1$ bai tipe 1 maupun tipe 2 kurang dipahami petani. Hal tersebut sesuai dengan kajian yang dilakukan oleh Mulijanti dan Sinaga (2014) dengan judul kajian Efektivitas Pendampingan Teknologi Tanam Jajar Legowo terhadap Perubahan Sikap dan Pengetahuan Petani di Kabupaten Sumedang Jawa Barat yang menyatakan bahwa Petani yang telah lama terbiasa dengan cara tanam tegel tentunya akan lebih sulit merubah kebiasaannya menerapkan cara tanam legowo.

Faktor lahan garapan dalam penelitian ini menghasilkan nilai koefisien yang tidak signifikan yang artinya tidak berpengaruh terhadap adopsi sistem tanam jajar legowo. Petani Desa Sukosari pada umumnya mempunyai lahan garapan yang tidak luas dengan ratarata luas lahan $\pm 0,6 \mathrm{Ha}$. Dengan lahan yang kurang luas dan mayoritas pengelolaannya adalah dilakukan sendiri menjadikan petani sangat hati-hati dan selektif untuk menerapkan suatu inovasi baru karena kekuatiran akan kegagalan yang berimbas pada menurunnya tingkat keuntungan. Hal tersebut sesuai penelitian yang dilakukan oleh Lalla (2012) yang berjudul Adopsi Petani Padi Sawah terhadap Sistem Tanam Jajar Legowo 2:1 Di Kecamatan Polongbangkeng Utara, Kabupaten Takalar yang menyatakan bahwa petani dengan lahan luas tidak menujukkan hubungan yang nyata karena petani cenderung menerapkan teknologi jajar legowo 2:1 hanya pada sebagian kecil lahan saja, meskipun dilakukan beberapa kali pada lahan yang sama untuk mengetahui tingkat perkembanganya. Ditambahakan juga dalam Soekartawi (2005), bahwa banyak teknologi maju baru yang memerlukan skala operasi yang besar dan sumberdaya ekonomi tinggi untuk keperluan adopsi inovasi dimana penggunaan teknologi pertanian yang lebih baik akan menghasilkan manfaat ekonomi yang memungkinkan perluasan usaha tani selanjutnya.

\section{Faktor Eksternal}

Faktor penyuluhan yang meliputi intensitas penyuluhan, materi penyuluhan, metode penyuluhan dan media penyuluhan tidak berpengaruh terhadap adopsi petani dalam menerapkan sistem tanam jajar legowo. Keempat faktor penyuluhan tersebut saling berkait dimana faktor intensitas menjadi faktor utama yang berdampak pada faktor penyuluhan lainnya. Intensitas penyuluhan petugas pada petani tentang sistem tanam jajar legowo tidak dilaksanakan secara rutin tapi hanya terlaksana saat munculnya program penyuluhan tentang jajar legowo dari dinas pertanian setempat. Namun demikian faktor penyuluhan tentang materi dan metode penyuluhan memiliki koefisien positif walaupun tidak berpengaruh yang berarti materi dan metode penyuluhan sistem tanam jajar legowo sebenarnya masih dibutuhkan oleh petani namun karena intensitasnya yang kurang rutin maka menjadikan faktor tersebut menjadi tidak berpengaruh. Hal tersebut sesuai dengan penelitian Lalla (2012), yang menyatakan bahwa Intensitas penyuluhan menujukkan hubungan tidak nyata dimana kurangnya intensitas pertemuan antara petani dan petugas dalam kegiatan penyuluhan mengakibatkan proses adopsi sistem tanam jajar legowo menjadi lambat. Hal tersebut diperparah dengan tidak rutinnya petani dalam mengikuti kegiatan penyuluhan karena kendala kesibukan petani dengan urusannya sendiri sehngga kegiatan penyuluhan hanya diwakilkan/digantikan oleh anak atau istrinya.

\section{Kesimpulan}

Berdasarkan distribusi sikap responden terhadap prinsip-prinsip teknologi sistem tanam jajar legowo di Desa Sukosari memiliki kecenderungan positif sebanyak $72,5 \%$. Faktor yang berpengaruh terhadap peluang adopsi sistem tanam jajar legowo adalah faktor umur, profitabilitas dan harga. Faktor umur dan profitabilitas berpengaruh signifikan positif sedangkan faktor harga berpengaruh signifikan negatif. Faktor lainnya yaitu pendidikan, pengalaman, lahan, intensitas penyuluhan, materi penyuluhan, metode penyuluhan dan media penyuluhan tidak mempunyai pengaruh signifikan terhadap peluang adopsi sistem tanam jajar legowo. Dengan demikian faktor umur, profitabilitas (keuntungan) dan harga merupakan faktor yang menentukan dalam proses adopsi sistem 
tanam jajar legowo di Desa Sukosari.

\section{Daftar Pustaka}

Anonim. 2017. Analisis Harga Gabah. BAPPEBTI Kementerian Perdagangan. [Internet]. https:// www.bappebti.go.id/id/news/commodity/ detail/4396.html. Diakses 2 Juni 2017.

BPS Kabupaten Malang. 2016. Kecamatan Kasembon Dalam Angka Tahun 2016. Malang (ID): BPS.

Damanik TR. 2012. Analisis Faktor-Faktor Yang Mempengaruhi Harga Jual Gabah Petani Di Serdang Bedagai. Bogor (ID): Jurnal Agribisnis, 7(4) Mei 2012.

Gujarati DN. 2006. Dasar-Dasar Ekonometrika. Jakarta (ID): Salemba Empat.

Kementan RI. 2015. Rencana Strategis Kementerian Pertanian 2015-2019. Jakarta (ID): Kementerian Pertanian Republik Indonesia.

Lalla H. 2012. Adopsi Petani Padi Sawah terhadap Sistem Tanam Jajar Legowo 2:1 di Kecamatan Polongbangkeng Utara Kabupaten Takalar. J. Sains \& Teknologi, 12(3) : 255-264

Mulijanti SL, Sinaga, A. 2014. Efektivitas Pendampingan Teknologi Tanam Jajar Legowo terhadap Perubahan Sikap dan Pengetahuan Petani di Kabupaten Sumedang Jawa Barat. Balai Pengkajian Teknologi Pertanian Jawa Barat.

Ningtyas RA. 2016. Tingkat Adopsi Sistem Tanam Jajar Legowo 2:1 di Kelompok Tani Mina Sri Jaya Desa Sepanjang Kecamatan Glenmore Kabupaten Banyuwangi Jawa Timur. E-Jurnal Agribisnis dan Agrowisata, 5(2) April 2016

Notoatmodjo. 2003. Pengembangan Sumber Daya Manusia. Jakarta (ID): PT Rineka Cipta.

Soekartawi. 2005. Prinsip Dasar Komunikasi Pertanian. Jakarta (ID): UI-Press.

UPT-BP Kecamatan Kasembon. 2017. Programa Penyuluhan Kecamatan Kasembon Tahun 2017. Malang (ID): UPT-BP Kecamatan Kasembon. 